\title{
PENGARUH CUSTOMER RELATIONSHIP MANAGEMENT (CRM) TERHADAP LOYALITAS KONSUMEN ASTRA MOTOR MT HARYONO DI BALIKPAPAN
}

\author{
Windi Agustin ${ }^{1}$, Ashari Sofyaun ${ }^{2}$, Prita Indriawati ${ }^{3}$ \\ Universitas Balikpapan ${ }^{1}$, Universitas Balikpapan ${ }^{2}$, Universitas Balikpapan ${ }^{3}$ \\ pos-el : windiagustin.wa@gmail.com¹, ashari.sofyaun@uniba-bpn.ac.id ${ }^{2}, \underline{\text { prita@, uniba-bpn.ac.id }{ }^{3}}$
}

\begin{abstract}
ABSTRAK
Penelitian ini dilatar belakangi oleh persaingan yang semakin kompetitif dari para perusahaan otomotif di Indonesia. Salah satu cara untuk memenangkan persaingan adalah dengan menerapkan Customer Relationship Management (CRM). Penerapan Customer Relationship Management (CRM) diharapkan mampu meningkatkan loyalitas konsumen yang pada akhirnya akan menciptakan konsumen yang loyal. Berdasarkan permasalahan tersebut, maka penelitian ini bertujuan untuk mengetahui pengaruh Customer Relationship Management (CRM) terhadap Loyalitas Konsumen. Jenis penelitian yang digunakan adalah Survei kuantitatif dengan metode penelitian kuantitatif. Populasi dalam penelitian ini adalah konsumen Astra Motor MT Haryono di Balikpapan. Sampel dalam penelitian ini berjumlah 160 orang dengan teknik pengambilan sampel menggunakan teknik sampel insidental. Hasil penelitian menunjukkan bahwa Customer Relationship Management (CRM) berpengaruh signifikan terhadap Loyalitas Pelanggan dengan koefisien determinasi $\left(\mathrm{R}^{2}\right)$ sebesar $14,91 \%$.
\end{abstract}

Kata kunci : Customer Relationship Management (CRM), Loyalitas Konsumen.

\begin{abstract}
This research is motivated by increasingly competitive competition from automotive companies in Indonesia. One way to win competition is to implement Customer Relationship Management (CRM). The application of Customer Relationship Management (CRM) is expected to increase consumer loyalty which in turn will create loyal customers. Based on these problems, this study aims to determine the effect of Customer Relationship Management (CRM) on Consumer Loyalty. The type of research used is quantitative survey with quantitative research methods. The population in this study were Astra Motor MT Haryono consumers in Balikpapan. The sample in this study amounted to 160 people with sampling techniques using incidental sample techniques. The results showed that Customer Relationship Management (CRM) had a significant effect on Customer Loyalty with a coefficient of determination (R2) of $14.91 \%$.
\end{abstract}

Keywords : Customer Relationship Management (CRM), Consumer Loyalty 


\begin{abstract}
1. PENDAHULUAN
Hadirnya suatu perusahaan memfokuskan bagaimana dapat mencapai profit yang maksimal untuk menjadikannya hal tersebut perusahaan harus siap menghadapi kompetisi begitu ketat. Kenyataan tersebut dapat dilihat dari banyaknya usaha pemasaran yang dilakukan oleh masing-masing perusahaan yang ada untuk mendapatkan hasil penjualan yang setinggi-tingginya memperoleh konsumen baru dan mempertahankan konsumen yang sudah ada. Selain itu kondisi pasar juga semakin terpecahpecah, daur produk semakin pendek dan adanya perubahan perilaku konsumen membuat pemasaran semakin penting.
\end{abstract}

Mengimplementasikan strategi Customer Relationship Management (CRM), perusahaan akan dapat menjalin hubungan dengan konsumen yang ada secara optimal sehingga dapat memenuhi keinginan konsumen dengan baik.

Keuntungan terbesar diperoleh perusahaan dari konsumen setia. Perusahaan dapat menjual lebih banyak barang atau jasa kepada konsumen yang telah mencoba dan mengenal produk dari perusahaan sehingga perusahaan harus mampu mempertahankan konsumen tersebut dan menjadikan konsumen yang loyal.

Berdasarkan dari situs resmi www.astramotor.co.id, menjelaskan bahwa perusahaan yang bergerak di bidang otomotif yang mendapatkan pengakuan resmi pemerintah Indonesia sebagai agen dalam menjual kendaraan bermotor bermerk Honda untuk seluruh wilayah Indonesia. Selain itu, Astra Motor MT Haryono bergerak dalam usaha importir suku cadang untuk sepeda motor dan juga memberikan jasa perawatan dan perbaikan kendaraan. Mempertahankan eksistensi Astra Motor MT Haryono sangat memperhatikan loyalitas konsumen. Penerapan Customer Relationship Management (CRM) atau managemen hubungan konsumen secara tidak langsung di katakan pengkomputerisasian data konsumen di maksudkan agar perusahaan mengetahui apa yang menjadi kebutuhan dan keinginan konsumen sehingga dapat terjalin hubungan yang baik dengan konsumen.

Dengan menerapkan Customer Relationship Management (CRM) ini Astra Motor MT Haryono melayani konsumen secara personal. Membangun database konsumen secara komprehensif. Astra Motor MT Haryono mememberikan layanan sesuai dengan kebutuhan konsumen. Identifikasi Masalah Berdasarkan latar belakang di tersebut, maka permasalahan dalam penelitian ini mengindentifikasi salah satu diantaranya adalah Masih Rendahnya tingkat loyalitas konsumen sebelumnya.

Sumber daya Manusia pada perusahaan kurang memanfaatkan pada database konsumen yang berisikan profil konsumen untuk memaksimalkan hubungan antara perusahaan dengan konsumen melalui penjualan. Kurang memanfaatkan pada teknologi yang sudah canggih dizaman modern ini 
sehingga menyiarkan sebuah berita maupun menawarkan produk tidak hanya pada media cetak saja tetapi juga bisa pada tayangan di sosial media, email, atau dapat menghubungi langsung pada konsumen tertentu untuk menawarkan sebuah jasa dan produk.

\section{METODE PENELITIAN}

Adapun pendekatan penelitian ini adalah deskriptif dan verifikatif. Menurut Nazir (2003:54) metode deskriptif adalah suatu metode dalam meneliti status sekelompok kelas peristiwa pada masa sekarang. Metode verifikatif menurut Nazir (2003:54) yaitu metode yang mencari korelasi atau hubungan kausal (menanyakan apakah ada hubungan terhadap objek yang kaan di teliti).

Tujuan dari penelitan ini adalah unurk membuat gambaran secara sistematis, faktual dan akurat mengenai fakta-fakta, sifat- sifat, hubungan antar fenomena yang diselidiki serta mendapatkan makna dan implikasi dari suatu masalah yang ingin dipecahkan. Dalam hal ini penulis menggunakan beberapa variabel yang digunakan dalam penelitian. Variabel adalah sesuatu yang memiliki variasi nilai dan mencerminkan konstruk. Jenis penelitian survei kuantitatif yang digunakan pada penelitian ini dimaksudkan untuk memperoleh informasi mengenai Pengaruh Customer Relationship Management terhadap loyalitas konsumen di Astra Motor MT Haryono secara mendalam.

Populasi Menurut Riduwan (2003:8) adalah objek atau subjek yang berada pada suatu wilayah dan memenuhi syarat-syarat tertentu berkaitan dengan masalah penelitian. Maka populasi yang akan diambil dalam penelitian ini adalah konsumen yang melakukan pembelian sepeda motor di Astra Motor MT Haryono.

Sampel menurut Riduwan (2003:10) adalah Sampel adalah bagian dari populasi yang mempunyai ciri-ciri atau keadaan tertentu yang akan di teliti. Oleh karena itu apabila populasi besar dan penelitian tidak mungkin dapat mempelajari semua yang ada pada populasi, maka peneliti dapat mengambil sebagian sampel untuk di teliti yang tentunya mewakili populasi. Sampel yang di gunakan adalah teknik sampling Insidental. Teknik Insidental ini merupakan teknik penentuan sampel secara kebetulan, yaitu siapa saja yang secara kebetulan bertemu dengan peneliti dan dapat di gunakan sebagai sampel.

\section{HASIL DAN PEMBAHASAN}

Berdasarkan dalam pengambilan sampel menurut rumus slovin penulis meneyebarkan 160 kuesioner kepada konsumen Walk in di Astra Motor MT Haryono. Kuesioner ini terdiri dari dua bagian, yaitu bagian pertama mengenai CRM (Customer Relationship Management) dan yang kedua mengenai Loyalitas konsumen terhadap Astra Motor MT Haryono.

Berdasarkan hasil output SPSS maka dapat di ketahui apa saja yang berpengaruh dan ada yang tidak secara parsial terhadap loyalitas konsumen. 
a. Variabel sumber daya manusia (x1) berpengaruh tidak signifikan dan negatif terhadap loyalitas konsumen. Dengan taraf 0.05 maka diperoleh hasil $0,05>0,535$ yang berarti tidak ada pengaruh yang signifikan antara variable independen terhadap variable dependen. Berdasarkan hasil perhitungan dari SPSS diperoleh nilai thitung sebesar 1.376. $\mathrm{t}$ tabel sebesar 1.960. Untuk itu hipotesa yang di ajukan dalam penelitian ini tidak terbukti sehingga di tolak.

b. Variabel teknologi (x2), secara parsial berpengaruh signifikan terhadap loyalitas konsumen. Dengan taraf tingkat signifikansi sebesar 5\% $(0,05)$, maka diperoleh hasil $0.006<0.05$ yang berarti ada pengaruh negatif yang signifikan antaravariabel independen terhadap variabel dependen. Berdasarkan hasil perhitungan dari SPSS diperoleh nilai t hitung sebesar 2.796. ttabel sebesar 1.960. Untuk itu hipotesa yang di ajukan dalam penelitian ini dapat diterima kebenarannya.

c. Variabel proses (x3). Secara parsial berpengaruh signifikan terhadap loyalitas konsumen. Dengan taraf tingkat signifikansi sebesar 5\% $(0,05)$, maka diperoleh hasil $0.018<$ 0.05 yang berarti ada pengaruh positif yang signifikan antara variabel independen terhadap variabel dependen. Berdasarkan hasil perhitungan dari SPSS diperoleh nilai thitung sebesar 2.390. $\mathrm{t}$ tabel sebesar 1.960. Untuk itu hipotesa yang di ajukan dalam penelitian ini dapat diterima kebenarannya.

d. Variabel pengetahuan (x4) secara parsial berpengaruh signifikan terhadap loyalitas konsumen. Dengan taraf tingkat signifikansi sebesar 5\% $(0,05)$, maka diperoleh hasil $0.032<0.05$ yang berarti ada pengaruh positif yang signifikan antara variable independen terhadap variabel dependen. Berdasarkan hasil perhitungan dari SPSS diperoleh nilai thitung sebesar 2.169. $\mathrm{t}$ tabel sebesar 1.960. Untuk itu hipotesa yang di ajukan dalam penelitian ini dapat diterima kebenarannya.6.2 Uji Statistik secara simultan ( Uji F ) Uji F dikenal dengan Uji serentak atau uji Model/Uji Anova, yaitu uji untuk melihat bagaimanakah pengaruh semua variabel bebasnya secara bersama-sama terhadap variabel terikatnya. Atau untuk menguji apakah model regresi yang kita buat baik/signifikan atau tidak baik/non signifikan. Jika model signifikan maka model bisa digunakan untuk prediksi/peramalan, sebaliknya jika non/tidak signifikan maka model regresi tidak bisa digunakan untuk peramalan.

\section{KESIMPULAN}

Berdasarkan uraian dan analisis yang telah di lakukan penulis pada bab sebelumnya, maka penulis menarik kesimpulan :

1. Terdapat adanya pengaruh negatif tidak signifikan pada sumber 


daya manusia terhadap loyalitas
konsumen, sumber daya manusia
rendah maka loyalitas konsumen
mengalami peningkatan
walaupun tidak signifikan.

2. Terdapat adanya pengaruh yang signifikan antar variabel teknologi terhadap loyalitas konsumen walaupun negatif.

3. Terdapat adanya pengaruh yang signifikan antar variabel teknologi terhadap loyalitas konsumen.

4. Terdapat adanya pengaruh yang signifikan antar variabel pengetahuan terhadap loyalitas konsumen.

5. Hasil hitung hipotesis yang ajukan di terima, sehingga dapat di simpulkan bahwa

pengaruh sumber daya manusia, teknologi, proses dan pengetahuan secara bersamasama terhadap loyalitas konsumen.

\section{DAFTAR PUSTAKA}

Bagdonien, Liudmila \& Rasa Jacksait. 2006. The Mission of Customer Loyalty Programmes \& Peculiariesties of Their Development.

Vadya/Management.

Buchari. Alma. 2004. Manajemen Pemasaran dan Pemasaran Jasa. Edisi Revisi. Bandung: CV. Alfabeta

Fullerton, Gordon. 2004. Putting the Relationship in CRM. The Workplace Review.

Gebert. Henning, Malte Geib, Lutz Kolbe \& Walter Brenner.
2003. Knowlegde: Integrating Customer Relationship Management Concept. Journal of Knowlegde Management.

Gordon, Ian. 2002. Best Pratice: Customer Relationship Management. Ivey Business Journal.

Griffin, Jill. 2005. Customer Loyalty: How to Keep, How to Earn it. Edisi Revisi. Bahasa Indonesia. Jakarta: Erlangga.

Hamdi, M.Si. 2007. Metode Penelitian dan Teori Organisasi. Malang: UMM Press.

Kartajaya, Hermawan. 2003. Mark Plus on Strategie: 12 Tahun Perjalanan

Markplus\&CoMembangun

Strategi Perusahaan. Jakarta: Penerbit Gramedia Pusaka Utama.

Kotler. Philip. 2005. Manajemen Pemasaran. Jilid 2. Edisi Sebelas, Jakarta: PT. Indeks.

Kevin Lane Keller. 2006. Marketing Managmenet. Jakarta: Pearson International Edition.

Kumar, Vijay \& W.J Reinartz. 2006. Customer Relationship Management:ADatabase

Approach. New York: John Wiley \& Sons.

Nazir, Moch. 2003. Metode Penelitian. Cetakan Kelima. Jakarta: Ghalia Indonesia. Osborne, Cathy. 2002. Strategy: Managing Customer Relationship. SMPS Marketers. Panda, Tapan K. 2003. Creating Customer Life Time Value Through Effective CRM in Financial Service Industry. Journal Service Research Volume 2, Number 2.

Riduwan DRS. M.B.A 2003. Dasar-dasar Statistik. Edisi Ketiga. Bandung: Alfabeta.

Sharp, Duane E. 2003. Customer Relationship 
Management System Handbook. London. Auerbach Publications.

Simamora, Bilson. 2004. Riset

Pemasaran. Edisi Pertama. Jakarta:

PT. Gramedia Pustaka Utama.

Sudjana. 2002. Statitik untuk

Ekonomi dan Niaga. Bandung:

Tarsito.

Sugiyono.2004.Metode

Penelitian Bisnis. Cetakan

Ketujuh: Alfabeta.

Umar, Husein. 2002. Metode

Riset Bisnis. Jakarta: PT.

Gramedia Pustaka Utama. Wagner,

William \& Michael

Zubey. 2007. Customer

Relationship Management: A
People, Process \& Technology Approach. Boston: Thomson Course Technology.

Zeihaml, A, Valerie \& Narry Jo Bitner. 2003. Service Marketing Edition. New Jersey: Mc. Grawn Hill.

Zikmun, William G., Raymond Mckeod Jr,. \& Faye W. Gilbert. 2003. Customer Relationship Management:Integrating Marketing Strategy and Information Teknology. USA: John Wiley \& Sons. 